\title{
Diversity of Oil Palm Insects in North Labuhanbatu
}

\author{
$1^{\text {st }}$ Irda Maya Farinsza ${ }^{1}, 2^{\text {nd }}$ B. Manurung ${ }^{2}, 3^{\text {rd }}$ D.S. Diningrat ${ }^{3}$ \\ \{irdafarinsz@gmail.com ${ }^{1}$ \} \\ Postgraduate Program, Universitas Negeri Medan, Indonesia ${ }^{1,2,3}$
}

\begin{abstract}
This study aims to determine the diversity of insects in oil palm plantations in the Marbau, North Labuhanbatu and its relative abundance. This research was conducted in 2 different lands, Immature Plantation Land (IPL) and Mature Plantation Land (MPL) with each land area of \pm 2 Ha with 3 observation stations diagonally. Sampling was carried out using the Pitfall Trap method for diurnal animals (active during the day), Light Trap (light traps) for nocturnal animals (active at night), and Sweep Net (net traps) for animals that were actively flying. The results of the research on IPL land were grouped into 8 orders, namely Coleoptera, Hemiptera, Orthoptera, Hymenoptera, Homoptera, Diptera, Lepidoptera and Isoptera. The order Hymenoptera (Formicidae) was the most common species with 393 individuals with the highest relative abundance of $76.2 \%$. The results of research on MPL land were grouped into 6 orders, namely Coleoptera, Himeptera, Orthoptera, Hymenoptera, Lepidoptera, and Odonata. order Hymenoptera (Formicidae) also has the most species, namely 471 individuals with the highest relative abundance of $102.2 \%$.
\end{abstract}

Keywords: insect, oil palm.

\section{Introduction}

Insects are part of the biodiversity that must be preserved from extinction or decline in species diversity. Insects have important values, including ecological values, endemism, conservation, education, culture, aesthetics and economics. The reason an ecosystem works well is because the relationship between the components involved in it undergoes a continuous exchange of substances and energy [1]. Insects are classified in the phylum Arthropoda [2]. Insects are one of the largest animal groups on earth. It is estimated that all insects account for three-quarters of all existing animals, and of these 750,000 species have been identified and named. This number is approximately $80 \%$ of the phylum itself.

In an ecosystem, the presence of fauna cannot be separated from the presence of flora as well, including the presence of oil palm plants which we often encounter. Oil palm comes from West Africa which is a renewable energy source and belongs to the Arecaceae family. Palm oil is the most widely produced and marketed vegetable oil-producing crop worldwide (75.70 million tons in 2019/2020 marketing). There are 3 types of oil palm, namely Dura (thick shell with thin mesocarp and high oil content), Psifera (without shell, with thick mesocarp and contains little oil), and the last is the Tenera type which is a hybrid plant of the Dura and Psifera species. (thin shell, thick mesocarp and contains a lot of oil) [3]. Until now, the Tenera type of oil palm is the oil palm that is widely cultivated by farmers because it has superior properties among others. 
In addition to its function as a source of renewable energy that is produced worldwide, we know that there are other negative impacts that arise due to the vast area of oil palm now. Deforestation which is then replaced by oil palm plantations has an impact on the environment and the biodiversity within it. The conversion of forests to oil palm plantations has an expansionary impact on environmental changes, including species decline in various taxa including insects (ants, beetles, bees, butterflies, and moths) as well as the order of arthropods (wood lice) [4]. All of these taxa, with the exception of bees, exhibit species decline indicating very high levels ofbiodiversity loss as a result of the gradual expansion of global oil palm.

The reason for the dramatic loss of species must be due to habitat simplification that occurs when forests are converted to oil palm land [4]. Reducing the complexity of the aboveground structures, and decreasing the height of the covered land, as well as climatic conditions in the plantations with warmer average temperatures and lower humidity levels.

North Labuhanbatu Regency is one of the regencies in North Sumatra which was formed in 2008 and is geographically located at 1058'-2050' North Latitude, 99025'-100005' East Longitude with an altitude of 0-700 m above sea level. North Labuhanbatu Regency consists of 8 sub-districts and 90 villages/kelurahan with a population of 363,816 people in 2019, according to the Central Statistics Agency of North Labuhanbatu (2019), occupies an area of $354,580 \mathrm{Ha}(3,545.80 \mathrm{~km} 2)$ and 78,399 Ha which includes an area of area used for oil palm cultivation [5].

The results of interviews with oil palm farmers in North Labuhanbatu that insects are often found when oil palms are 0-12 months old. The abundance of insect populations is also influenced by the rainy season. The results of the interview also found that there was no research on the diversity of insects on oil palm plants in the district. Marbau, Kab. North Labuhanbatu. So based on this background, a study that aims to look at the diversity of oil palm insects and their relative abundance would like to be carried out.

\section{Method}

This research was conducted in March-June 2021 in individual oil palm plantations in Kec. Marbau, Kab. North Labuhanbatu, North Sumatra. Insect identification was carried out at the Faculty of Mathematics and Natural Sciences, Medan State University.

The materials used in this study were insects caught as research objects, clean water, detergent, and $70 \%$ alcohol. The tools used in this study were jars, sample bottles, sweep nets, light traps, pitfall traps, cameras, machetes, stationery, data books, and the reference book Identification of Insect Types and Functions [6] and the book Key to Insect Determination [7].

This activity is carried out by taking and collecting insects caught at each observation station using various methods of taking insects. Sampling locations were carried out in 2 different lands, namely in Immature Plantation Land (TBM) covering an area of $\pm 2 \mathrm{Ha}$ with a plant age of 2 years. Sampling was carried out at 3 points of observation stations diagonally, and Land for Mature Plants (TM) which has the same area as the age of 10 years of plants with sampling at 3 stations diagonally as well. Catching insects is carried out using various traps, including sweep nets used to catch insects that are actively flying, pitfall traps used to trap insects that are active during the day (diurnal insects) and live above ground level. , and light traps are used to trap insects that are active at night (nocturnal insects).

Insect samples that have been obtained from the field are brought to the laboratory which are then grouped according to the sampling location and preserved with $70 \%$ alcohol. 
Furthermore, insects were identified using the reference book Identification of Insect Species and Functions [6] and the book Key to Insect Determination [7].

Relative abundance is the ratio between the number of individual species and the total number of individuals of all species [8]. Relative abundance is calculated by comparing the abundance of an insect species with the abundance of all types of insects contained in the sample unit [9]. Relative abundance can be calculated by:

$$
\mathrm{Kr}=\frac{K i}{\sum K} \times 100 \%
$$

Information:

$\mathrm{Kr}$ : Relative abundance of species

$\mathrm{Ki}$ : Number of individuals for species i

$\mathrm{K}$ : Total number of individuals of all Species

\section{Results and Discussion}

\subsection{Immature Plants Land (IPL)}

Pitfall Trap. Anoplolepis gracilipes from the Formicidae family had the highest number of individuals in the pitfall trap with a total of 76 individuals, and Hierodula membranacea from the Mantidae family with the least number of individuals with a total of 1 individual. The highest relative abundance of species is also in line with the absolute abundance of the species with a percentage of $16.3 \%$ belonging to the species Anoplolepis gracilipes and the lowest relative abundance belonging to the species Hierodula membranacea with a percentage of $0.2 \%$. The overall relative abundance of insect species in the Immature Plants Land (IPL) area using a pitfall trap can be seen in Table 1 below.

Table 1. Relative abundance of insect species in the Immature Plants Land (IPL) area using a pitfall trap.

\begin{tabular}{|c|c|c|c|c|c|c|c|c|}
\hline \multirow[t]{3}{*}{ No } & \multicolumn{3}{|c|}{ Classification } & \multicolumn{3}{|c|}{ Week } & \multicolumn{2}{|c|}{ Abundance } \\
\hline & \multirow[t]{2}{*}{ Ordo } & \multirow[t]{2}{*}{ Famili } & \multirow[t]{2}{*}{ Species } & & & & Absolut & Relatif \\
\hline & & & & I & II & III & & $(\%)$ \\
\hline \multirow[t]{3}{*}{1} & Coleoptera & Scarabaeidaea & Apogoniaexpeditionis & 11 & 5 & 5 & 21 & 4.5 \\
\hline & & Carabidae & Bembidiontetracolum & 10 & 6 & 3 & 19 & 4 \\
\hline & & & Dicranoncusfemoralis & 4 & 1 & 4 & 9 & 1.9 \\
\hline \multirow[t]{6}{*}{2} & Hemiptera & Pyrrhocoridae & Dysdercuscingulatus & 8 & 5 & - & 13 & 2.7 \\
\hline & & Reduviidae & Cosmolestespicticeps & 18 & 21 & 8 & 47 & 10.1 \\
\hline & & & Rhynocorisfuscipes & 18 & 21 & 9 & 48 & 10.3 \\
\hline & & Alydidae & Leptocorisaacuta & 6 & 4 & 2 & 12 & 2.5 \\
\hline & & & Riptortuslinearis & 5 & 2 & 2 & 9 & 1.9 \\
\hline & & Coreidae & $\begin{array}{l}\text { Homoeocerusmarginell } \\
\text { us }\end{array}$ & 4 & - & 4 & 8 & 1.7 \\
\hline \multirow[t]{2}{*}{3} & Orthoptera & Mantidae & $\begin{array}{l}\text { Hierodulamembranace } \\
a\end{array}$ & - & - & 1 & 1 & 0.2 \\
\hline & & Tettigoniidae & Phaneroptera nana & - & - & 1 & 1 & 0.2 \\
\hline
\end{tabular}




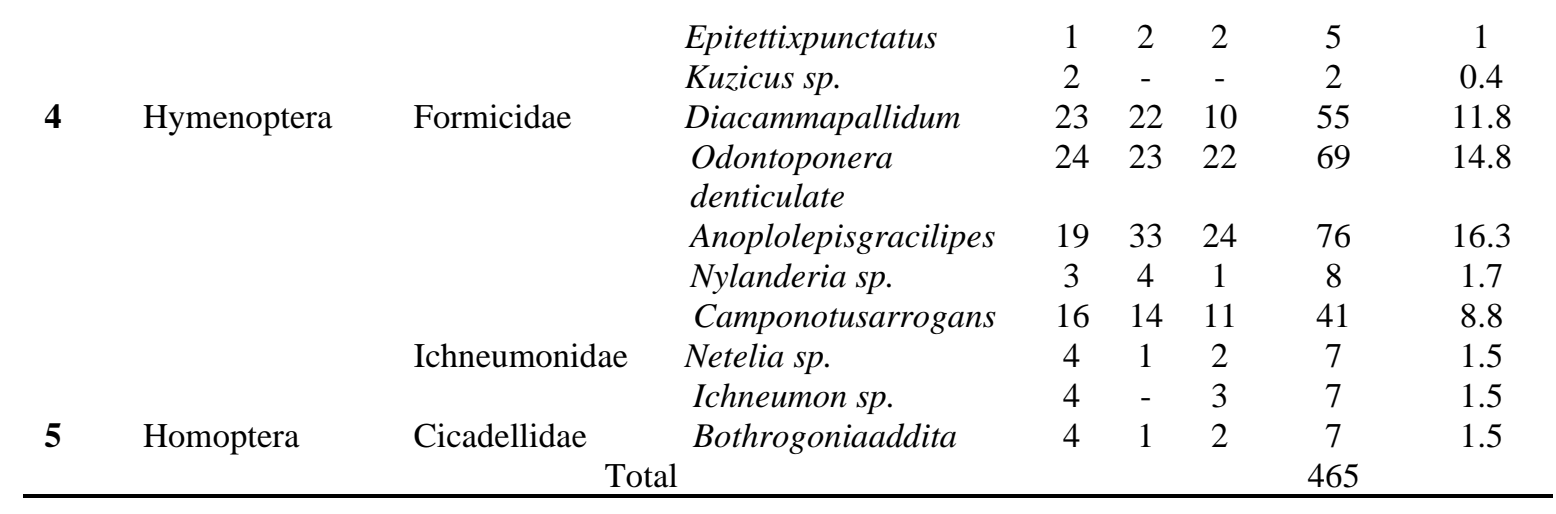

Light Trap. Camponotus sp. from the Formicidae family had the highest number of individuals in the pitfall trap with a total of 115 individuals, and Xylotrupes gideon from the Scarabaeidaea family with the least number of individuals with a total of 1 individual. The highest relative abundance of species is also in line with the absolute abundance of these species with a percentage of $18.2 \%$ owned by Camponotus sp. and the lowest relative abundance was owned by Xylotrupes gideon with a percentage of $0.1 \%$. The overall relative abundance of insect species in the Immature Plants Land (IPL) area using light traps can be seen in Table 2 below.

Table 2. Relative abundance of insect species in the Immature Plants Land (IPL) area using light traps.

\begin{tabular}{|c|c|c|c|c|c|c|c|c|}
\hline \multirow[t]{3}{*}{ No } & \multicolumn{3}{|c|}{ Classification } & \multirow{2}{*}{\multicolumn{3}{|c|}{ Week }} & \multicolumn{2}{|c|}{ Abundance } \\
\hline & \multirow[t]{2}{*}{ Ordo } & \multirow[t]{2}{*}{ Famili } & \multirow[t]{2}{*}{ Species } & & & & & \\
\hline & & & & I & II & III & Absolut & Relatif (\%) \\
\hline \multirow[t]{6}{*}{1} & \multirow[t]{6}{*}{ Hymenoptera } & Braconidae & Spinariaspinator & 46 & 28 & 27 & 101 & 16 \\
\hline & & Formicidae & Camponotus sp. & 51 & 37 & 27 & 115 & 18.2 \\
\hline & & & $\begin{array}{l}\text { Odontoponera } \\
\text { denticulate }\end{array}$ & 9 & 11 & 9 & 29 & 4.6 \\
\hline & & Ichneumonidae & Ichneumon sp. & 18 & 18 & 19 & 55 & 8.7 \\
\hline & & & Netelia sp. & 18 & 16 & 18 & 52 & 8.2 \\
\hline & & Sphecidae & Isodontiaexonata & 9 & 11 & 9 & 29 & 4.6 \\
\hline \multirow[t]{3}{*}{2} & \multirow[t]{3}{*}{ Lepidoptera } & Limacodidae & Setoranitens & 18 & 18 & 17 & 53 & 8.4 \\
\hline & & Erebidae & Anomiserosa & 12 & 12 & 7 & 31 & 4.9 \\
\hline & & & Lyclene reticulate & 9 & 11 & 9 & 28 & 4.4 \\
\hline \multirow{2}{*}{3} & \multirow{2}{*}{ Orthoptera } & Gryllidae & Achetadomesticus & 24 & 25 & 24 & 73 & 11.6 \\
\hline & & Tettigoniidae & $\begin{array}{l}\text { Conocephaluslongipe } \\
\text { nnis }\end{array}$ & 2 & 6 & 1 & 9 & 1.4 \\
\hline \multirow[t]{7}{*}{4} & \multirow[t]{7}{*}{ Coleoptera } & Scarabaeidaea & Xylotrupesgideon & - & - & 1 & 1 & 0.1 \\
\hline & & & Adoretuscompressus & 5 & 4 & 3 & 12 & 1.9 \\
\hline & & & Adoretussinicus & 1 & 4 & 2 & 7 & 1.1 \\
\hline & & & Anomalapallida & 4 & 5 & 3 & 12 & 1.9 \\
\hline & & & Dyscinetuspicipes & 3 & 4 & 2 & 9 & 1.4 \\
\hline & & Lycidae & Calopteronterminale & 7 & 2 & 4 & 13 & 2 \\
\hline & & \multicolumn{2}{|c|}{ Total } & & & & 629 & \\
\hline
\end{tabular}


Sweep Net. Acraea terpsicore from the Nymphalidae family had the highest number of individuals in the sweep net with 182 individuals, and Xylocopa confuse from the Apidae family with the least number of individuals with a total of 3 individuals. The highest relative abundance of species is also in line with the absolute abundance of that species with a percentage of $18.2 \%$ belonging to the species Acraea terpsicore and the lowest relative abundance belonging to the species Xylocopa confuse with a percentage of $3 \%$. The overall relative abundance of insect species in the Immature Plants area (TBM) using a sweep net can be seen in Table 3 below.

Table 3. Relative abundance of insect species in the Immature Plants Land (IPL) using a sweep net.

\begin{tabular}{|c|c|c|c|c|c|c|c|c|}
\hline \multirow[t]{3}{*}{ No } & \multicolumn{3}{|c|}{ Classification } & \multirow{2}{*}{\multicolumn{3}{|c|}{ Week }} & \multicolumn{2}{|c|}{ Abundance } \\
\hline & \multirow[t]{2}{*}{ Ordo } & \multirow[t]{2}{*}{ Famili } & \multirow[t]{2}{*}{ Species } & & & & & \\
\hline & & & & I & II & III & Absolut & Relatif $(\%)$ \\
\hline 1 & Coleoptera & Coccinellidae & Propyleadissecta & 22 & 26 & 32 & 80 & 8 \\
\hline \multirow[t]{2}{*}{2} & Diptera & Asilidae & Efferia sp. & 5 & 5 & 3 & 13 & 1.3 \\
\hline & & Syrphidae & $\begin{array}{l}\text { Eristalinusmegac } \\
\text { ephalus }\end{array}$ & 4 & 6 & 3 & 13 & 1.3 \\
\hline \multirow[t]{12}{*}{3} & Hymenoptera & Halictidae & Lasioglossumsp & 7 & 9 & 6 & 22 & 2.2 \\
\hline & & & $\begin{array}{l}\text { Lipotrichesflavovi } \\
\text { ridis }\end{array}$ & 8 & 10 & - & 18 & 1.8 \\
\hline & & & Nomiaelegans & 9 & 9 & 5 & 23 & 2.3 \\
\hline & & & Nomiaincerta & 6 & 8 & 6 & 20 & 2 \\
\hline & & & Nomiairidenscens & 10 & 11 & 8 & 29 & 2.9 \\
\hline & & & Nomiathoracica & 9 & 11 & 9 & 29 & 2.9 \\
\hline & & Vespidae & $\begin{array}{l}\text { Delta } \\
\text { campaniforme }\end{array}$ & 11 & 10 & 6 & 27 & 2.7 \\
\hline & & & Delta pyriforme & 3 & 4 & 5 & 12 & 1.2 \\
\hline & & & $\begin{array}{l}\text { Eustenogasterfrat } \\
\text { erna }\end{array}$ & 4 & 5 & 5 & 14 & 1.4 \\
\hline & & & $\begin{array}{l}\text { Rhynchiumhaemo } \\
\text { rrhoidale }\end{array}$ & 7 & 8 & 10 & 25 & 2.5 \\
\hline & & Apidae & Xylocopa confuse & - & - & 3 & 3 & 3 \\
\hline & & Scoliidae & Scolia sp. & 2 & - & 2 & 4 & 4 \\
\hline \multirow[t]{10}{*}{4} & Lepidoptera & Lycaenidae & Jamidesalecto & 36 & 29 & 33 & 98 & 9.8 \\
\hline & & & Zizinaotis & 35 & 32 & 29 & 96 & 9.6 \\
\hline & & Nymphalidae & Acraeaterpsicore & 66 & 54 & 62 & 182 & 18.2 \\
\hline & & & Ideopsis vulgaris & 2 & 2 & 3 & 7 & 7 \\
\hline & & & Junoniaalmana & 15 & 19 & 16 & 50 & 5 \\
\hline & & & Junoniaorithya & 20 & 22 & 12 & 54 & 5.4 \\
\hline & & & Neptishylas & 6 & 5 & 2 & 13 & 1.3 \\
\hline & & & Ypthimabaldus & 15 & 7 & 7 & 29 & 2.9 \\
\hline & & Pieridae & Appiaslibythea & 22 & 19 & 17 & 58 & 5.8 \\
\hline & & & Euremahecabe & 8 & 12 & 12 & 32 & 3.2 \\
\hline \multirow[t]{2}{*}{5} & Isoptera & Tachinidae & Rutilotrixa sp. & 16 & 18 & 15 & 49 & 4.9 \\
\hline & \multicolumn{3}{|c|}{ Total } & & & & 1000 & \\
\hline
\end{tabular}




\subsection{Mature Plants Land (MPL)}

Pitfall Trap. Odontoponera denticulate from the Formicidae family had the highest number of individuals in the pitfall trap with a total of 121 individuals, and Epitettix punctatus from the Tettigoniidae family with the least number of individuals with a total of 5 individuals. The highest relative abundance of species is also in line with the absolute abundance of these species with a percentage of $27.8 \%$ belonging to the species Odontoponera denticulate and the lowest relative abundance belonging to the species Epitettix punctatus with a percentage of $1.1 \%$. The overall relative abundance of insect species in Mature Crops (TM) areas using a pitfall trap can be seen in Table 4 below.

Table 4. Relative abundance of insect species in Mature Crops (TM) areas using a pitfall trap.

\begin{tabular}{|c|c|c|c|c|c|c|c|c|}
\hline \multirow[t]{3}{*}{ No } & \multicolumn{3}{|c|}{ Classification } & \multirow{2}{*}{\multicolumn{3}{|c|}{ Week }} & \multicolumn{2}{|c|}{ Abundance } \\
\hline & \multirow[t]{2}{*}{ Ordo } & \multirow[t]{2}{*}{ Famili } & \multirow[t]{2}{*}{ Species } & & & & & \\
\hline & & & & I & II & III & Absolut & Relatif (\%) \\
\hline 1 & Coleoptera & Scarabaeidaea & $\begin{array}{l}\text { Apogoniaexpediti } \\
\text { onis }\end{array}$ & 12 & 5 & 7 & 24 & 5.5 \\
\hline \multirow[t]{3}{*}{2} & Hemiptera & Alydidae & Leptocorisaacuta & 9 & 4 & 10 & 23 & 5.2 \\
\hline & & & Riptortuslinearis & 5 & 10 & 12 & 27 & 6.2 \\
\hline & & Coreidae & $\begin{array}{l}\text { Homoeocerusmar } \\
\text { ginellus }\end{array}$ & 4 & - & 4 & 8 & 1.8 \\
\hline \multirow[t]{2}{*}{3} & Orthoptera & Tettigoniidae & Epitettixpunctatus & 1 & 2 & 2 & 5 & 1.1 \\
\hline & & & Kuzicus sp. & 4 & - & 2 & 6 & 1.3 \\
\hline \multirow[t]{6}{*}{4} & Hymenoptera & Formicidae & $\begin{array}{l}\text { Diacammapallidu } \\
m\end{array}$ & 23 & 26 & 17 & 66 & 15.2 \\
\hline & & & $\begin{array}{l}\text { Odontoponera } \\
\text { denticulate }\end{array}$ & 44 & 40 & 37 & 121 & 27.8 \\
\hline & & & $\begin{array}{l}\text { Anoplolepisgracil } \\
\text { ipes }\end{array}$ & 28 & 33 & 22 & 83 & 19.1 \\
\hline & & & Nylanderia sp. & 10 & 4 & 3 & 17 & 3.9 \\
\hline & & & $\begin{array}{l}\text { Camponotusarro } \\
\text { gans }\end{array}$ & 21 & 18 & 15 & 54 & 12.4 \\
\hline & \multicolumn{3}{|c|}{ Total } & & & & 434 & \\
\hline
\end{tabular}

Light Trap. Camponotus sp. from the Formicidae family had the highest number of individuals in the sweep net with a total of 94 individuals, and Conocephalus longipennis from the Tettigoniidae family with the least number of individuals with a total of 7 individuals. The highest relative abundance of species is also in line with the absolute abundance of these species with a percentage of $17.2 \%$ belonging to Camponotus sp. and the lowest relative abundance was Conocephalus longipennis with a percentage of $1.2 \%$. The overall relative abundance of insect species in the Mature Plants Land (MPL) area using a sweep net can be seen in Table 5 below. 
Table 5. Relative abundance of insect species in the Mature Plants Land (MPL) area using a sweep net.

\begin{tabular}{|c|c|c|c|c|c|c|c|c|}
\hline \multirow[t]{5}{*}{ No } & \multicolumn{3}{|c|}{ Classification } & \multirow{2}{*}{\multicolumn{3}{|c|}{ Week }} & \multirow{2}{*}{\multicolumn{2}{|c|}{ Abundance }} \\
\hline & \multirow[t]{4}{*}{ Ordo } & Famili & Species & & & & & \\
\hline & & & & I & II & III & Absolut & Relatif $(\%)$ \\
\hline & & Braconidae & Spinariaspinator & 38 & 28 & 22 & 88 & 16.1 \\
\hline & & Formicidae & Camponotus sp. & 40 & 29 & 25 & 94 & 17.2 \\
\hline \multirow[t]{4}{*}{1} & \multirow[t]{4}{*}{ Hymenoptera } & & Odontoponera denticulate & 9 & 14 & 13 & 36 & 6.6 \\
\hline & & Ichneumonidae & Ichneumon sp. & 9 & 11 & 9 & 32 & 5.8 \\
\hline & & & Netelia sp. & 17 & 15 & 19 & 51 & 9.3 \\
\hline & & Limacodidae & Setoranitens & 21 & 21 & 21 & 63 & 11.5 \\
\hline \multirow[t]{2}{*}{2} & \multirow{2}{*}{ Lepidoptera } & Erebidae & Anomiserosa & 13 & 6 & 7 & 26 & 4.7 \\
\hline & & & Lyclene reticulate & 7 & 7 & 12 & 26 & 4.7 \\
\hline \multirow{3}{*}{3} & \multirow{3}{*}{ Orthoptera } & Gryllidae & Achetadomesticus & 25 & 26 & 29 & 80 & 14.7 \\
\hline & & Tettigoniidae & Conocephaluslongipennis & - & 6 & 1 & 7 & 1.2 \\
\hline & & Scarabaeidaea & Adoretuscompressus & 3 & 3 & 2 & 8 & 1.4 \\
\hline \multirow{5}{*}{4} & \multirow{5}{*}{ Coleoptera } & & Adoretussinicus & 1 & 4 & 3 & 8 & 1.4 \\
\hline & & & Anomalapallida & 2 & 3 & 2 & 7 & 1.2 \\
\hline & & & Dyscinetuspicipes & 4 & 4 & 2 & 10 & 1.8 \\
\hline & & Lycidae & Calopteronterminale & 4 & 2 & 4 & 8 & 1.4 \\
\hline & & & otal & & & & 544 & \\
\hline
\end{tabular}

Sweep Net. Neurothemis fluctuans from the Libellulidae family had the highest number of individuals in the sweep net with a total of 105 individuals, and Ideopsis vulgaris from the Nymphalidae family with the least number of individuals with a total of 1 individual. The highest relative abundance of species is also in line with the absolute abundance of these species with a percentage of $43.3 \%$ belonging to the species Neurothemis fluctuans and the lowest relative abundance belonging to the species Ideopsis vulgaris with a percentage of $0.4 \%$. The overall relative abundance of insect species in the Mature Plants Land (MPL) area using a sweep net can be seen in Table 6 below.

Table 6. Relative abundance of insect species in the Mature Plants Land (MPL) area using a sweep net.

\begin{tabular}{|c|c|c|c|c|c|c|c|c|}
\hline \multirow[t]{3}{*}{ No } & \multicolumn{3}{|c|}{ Classification } & \multicolumn{3}{|c|}{ Week } & \multicolumn{2}{|c|}{ Abundance } \\
\hline & Ordo & Famili & Species & & & & & \\
\hline & & & & I & II & III & Absolut & Relatif $(\%)$ \\
\hline \multirow[t]{10}{*}{1} & Lepidoptera & Lycaenidae & Jamidesalecto & 1 & 3 & - & 4 & 1.6 \\
\hline & & & Zizinaotis & 2 & 2 & - & 4 & 1.6 \\
\hline & & Nymphalidae & Ariadne ariadne & 7 & 4 & 6 & 17 & 7 \\
\hline & & & Ideopsis vulgaris & - & 1 & - & 1 & 0.4 \\
\hline & & & Junoniaalmana & 4 & 2 & 3 & 9 & 3.7 \\
\hline & & & Junoniaorithya & 3 & 3 & 3 & 9 & 3.7 \\
\hline & & & Neptishylas & 6 & 5 & 2 & 13 & 5.3 \\
\hline & & & Ypthimabaldus & 4 & 2 & 3 & 9 & 3.7 \\
\hline & & Pieridae & Appiaslibythea & 3 & - & 1 & 4 & 1.6 \\
\hline & & & Euremahecabe & 2 & - & 2 & 4 & 1.6 \\
\hline 2 & Odonata & Libellulidae & Neurothemisfluctuans & 44 & 32 & 29 & 105 & 43.3 \\
\hline
\end{tabular}




\begin{tabular}{lccccc} 
Aethriamantagracilis & 19 & 15 & 17 & 51 & 21 \\
$\begin{array}{l}\text { Nesoxenialineata } \\
\text { Total }\end{array}$ & 4 & 4 & 4 & 12 & 4.9 \\
\hline
\end{tabular}

The Immature Plantation Land studied by the researchers was 2.5 years old with a fairly high diversity of plants in it. There are many sugarcane, corn, papaya, and herbaceous plants. The land used by the researcher is $\pm 2 \mathrm{Ha}$ by using 3 points of the research location diagonally. Catching insects using 3 methods, namely pitfall traps, light traps, and sweep nets while the Mature Plantation Land studied by the researcher is \pm 10 years old with the same land area and method.

In immature oil palm land, there are still many types of insects because they still have many companion plants planted by the garden owner, so the presence of insects is still a lot because the food sources for these insects are sufficient. There were several types of wasps found by researchers at the second observation point. The wasps are in the shrubs around the oil palm plants. Butterflies are also like that, diverse due to the large number of plants in the oil palm area. This is in line with what Mahrub (1999) said in [10] that the diversity and abundance of insects is in line with the development of plants as their habitat. This proves that high vegetation causes a high abundance of insects as well.

The Formicidae (ants) family has a way of living in colonies and has a population of up to $70 \%$ of the soil fauna population, so they are often found in large numbers [1]. Ants have a role in the rate of decomposition because ants are soil insects that can destroy dead animals and plants. The high presence of species from the order Lepidoptera with a relative abundance of $34,6 \%$ makes garden owners need not worry. This is due to the fact that species from the order Lepidoptera are natural enemies of the caterpillar pests that usually attack oil palm leaves.

The thing that is most feared in oil palm plantations is the presence of caterpillars which become pests for oil palm plants [11]. Fire caterpillars from the order Lepidoptera (Limacodidae) are capable of producing 300-400 eggs per day. From the results of the study, it was found that the relative order of Lepidoptera (Limacodidae) was lower (2.5\%) compared to the relative of the caterpillar predators themselves from the order Hemiptera (Reduviidae) (4.5\%). The results also found that species that have high relatives from the order Lepidoptera are species from the Nymphalidae family.

In addition, at least species of the family Acrididae and Tettigonidae (Ordo orthoptera) are also beneficial for garden owners. According to data, \pm 51 species of members of the family Acrididae were recorded as pests. The Orthoptera order has always been a problem in society because the order includes plant pests that cause harm to humans, thus disrupting economic aspects [12].

\section{Conclusion}

Based on the results of the study, it can be concluded that the diversity of oil palm insects in Immature Plants (IBM) is grouped into 8 orders, namely Coleoptera, Hemiptera, Orthoptera, Hymenoptera, Homoptera, Diptera, Lepidoptera and Isoptera. The order Hymenoptera (Formicidae) was the most common species with 393 individuals with the highest relative abundance of $18.7 \%$. The results of research on TM land were grouped into 6 orders, namely Coleoptera, Himeptera, Orthoptera, Hymenoptera, Lepidoptera, and Odonata. 
order Hymenoptera (Formicidae) also has the most species, namely 471 individuals with the highest relative abundance of $38.6 \%$.

\section{References}

[1] Haneda NF, Sirait BA. Keanekaragaman Fauna Tanah dan Peranannya terhadap Laju Dekomposisi Serasah Kelapa Sawit (ElaeisguineensisJacq). J Silvikultur Tropika. 2012; 3(3):161-167.

[2] Falahuddin, Irham, Pane ER, Mawar E. Identifikasi Serangga Ordo Coleoptera pada Tanaman Mentimun (CucumisSativus L) di Desa Tirta Mulya Kecamatan Makarti Jaya Kabupaten Banyuasin II. J Biota. 2015; 1(1):9-15.

[3] Mozzon M, Foligni R, Mannozzi C. Current Knowledge on Interspecific Hybrid Palm Oils as Food and Food Ingredient. Food. 2020; 9:1-16.

[4] Turner PD, Gillbanks RA. Oil Palm Cultivation and Management. $2^{\text {nd }}$ Edition. Kuala Lumpur: The Incorporated of Planters Society; 2003.

[5] BPS-Statistics of Labuhan batu Utara Regency. Kabupaten Labuhanbatu Utara dalam Angka. Badan Pusat Statistik Kabupaten Labuhanbatu Utara; 2018.

[6] Borror DJ, Triplehorn CA, Johnson NF. Pengenalan Pelajaran Serangga. $6^{\text {th }}$ Edition. Yogyakarta: Gadjah Mada University Press; 1996.

[7] Siwi S. Kunci Determinasi Serangga. Yogyakarta: Karnisius; 2006.

[8] Suin MH. Ekologi Hewan Tanah. Bandung: Bumi Aksara; 2012.

[9] Hariyanto S, et al. Teori dan Praktik Ekologi. Surabaya: Airlangga Universiti Press; 2008.

[10] Diputra DN. Keanekaragaman Arthropoda pada Ekosistem Pertanaman Bawang Merah (Allium ascolonicum L.) dengan Aplikasi dan Tanpa Aplikasi Insektisida. Palu: Universitas Tadulako; 2012. 1-11.

[11] Sihombing DPA. Keanekaragaman Jenis Serangga Tanaman Kelapa Sawit di Perkebunan Minanga Ogan Kabupaten Oku dan Sumbangannya pada Pembelajaran Biologi SMA. J Pembelajaran Biologi. 2015; 2(2):174-184.

[12] Fakrah. Inventarisasi Insekta Permukaan Tanah di Gampong Krueng Simpo Kecamatan Juli Kabupaten Bireuen. J Pendidikan Almuslim. 2016; 4(1):48-52. 